\title{
Study on energy and water balance of pepper field in arid areas
}

\author{
Qingtao Zhang ${ }^{1}$, Zhiqiang Wang ${ }^{1}$, Zijun $\mathrm{Ke}^{1}$, Xinyu Wu${ }^{1}$, Bei Wang ${ }^{2}$, and Guo Yu Qiu ${ }^{2}$ \\ ${ }^{1}$ Sun Yat-Sen University \\ ${ }^{2}$ Peking University Shenzhen Graduate School
}

February 1, 2022

\begin{abstract}
The middle Heihe River Basin (MHRB) in arid areas in China faces the challenge of sustainability, but frequent over-irrigation deteriorated the situation. The water balance and energy budget have not been widely used for the quantifying evaluation of over-irrigation. Although some studies have measured the energy budget and water balance in cropland, the energy and water balance in pepper fields is still unclear. An experiment was conducted using an eddy covariance system, SmartView fluke and other measurements in MHRB. The leaf area index (LAI) for pepper increased in the first two months, then decreased thereafter. After Aug. 4, the daily evapotranspiration (ET) decreased during the maturation stage. The soil moisture was higher than the field capacity frequently, indicating that over-irrigation had occurred. Soil water content was relatively high at $100 \mathrm{~cm}$ depth, causing high percolation. The water inputs were 1.5 times ET, and the deep percolations accounted for $74 \%$ of the total irrigation inputs. Irrigation water could be conserved $301 \mathrm{~mm}$, in case that percolation was avoided. Therefore, the irrigation amount (per time and total) should be reduced to achieve high water use efficiency (WUE). The latent heat flux (LE) consumed $80 \%$ of the net radiation (Rn). In July, the LE/Rn was the highest among all months, whereas H/Rn was the lowest due to the highest value of LAI in July. The net radiation had a significant positive linear correlation with the latent heat flux because of the high water supply. Our study showed that there was considerable room for water conservation in MHRB. Keywords: Sensible heat flux; Soil water content; Evapotranspiration; Latent heat flux; Leaf area index
\end{abstract}

\section{Introduction}

Drought and unsustainable water use are becoming major obstacles to economic welfare and sustainable development in arid areas (Zhang et al., 2018). Water and energy balances are necessary for efficient irrigation scheduling at field scale (Roost et al., 2008; Taghvaeian and Neale, 2011; Knipper et al., 2020).

The Heihe River Basin (HRB) is the second largest inland river basin in northwestern China. Irrigation in the middle reaches of the Heihe River Basin (MHRB) represents more than $90 \%$ of water consumption, which causes desertification and lake contraction of the lower reaches (Fu et al., 2014; Tan, 2019). Water deficit and competition have increased in the last decades (Qi and Luo, 2005), which has led to a decrease in the water allocated for MHRB.

Li et al. (2018) found that the overexploitation led to a reduction in the groundwater table in MHRB. Meanwhile, irrigation water is not efficiently consumed for agriculture (Li, 2020). Most of fields in MHRB were owned by commercial companies, which aim to achieve high yields rather than saving water. Therefore quantifying the agricultural water use in MHRB is important to the efficient and fair allocation of the precious water resources for both the local economy and the natural environment protection. Moreover, the water balance and energy budget have not been widely used for the quantifying evaluation of over-irrigation (Yang et al., 2015), especially in pepper fields.

Evapotranspiration $(E T)$ is a considerable part of the water budget as well as the energy balance, and strongly controls energy transport and water cycling (Tian et al., 2013; Haghighi and Kirchner, 2017). In 
addition, ET is related to soil moisture, therefore an accurate estimation of $E T$ for irrigated agriculture is fatal for the efficient management of water resources in arid areas $(\mathrm{Li}, 2020)$. In the past, ET, water and energy budgets were difficult to get due to the backward observation technique in MHRB. Fortunately, the eddy covariance (EC) technique employs micrometeorological mass transfer methods to measure the energy budget and ET (Uddin et al., 2013). During the last decade, several studies were conducted to measure sensible heat flux $(H)$ and latent heat flux $(L E)$ above the maize canopy in MHRB using the EC method (Ji et al., 2011; Ma et al., 2015; Xu et al., 2017).

Through $E T$ and $L E$, the energy budget is closely associated with the water balance. Hence, research on the energy budget of croplands is critical for understanding the water budget for decision makers (Cheng et al., 2014). Although some studies have measured the energy budget (Gao et al., 2018) and water balance in cropland, few have studied the energy budget and water balance in pepper (one of the representative vegetables in MHRB) fields. The plant area for pepper in China represented $35 \%$ of the gross area for pepper in the world (Huo et al., 2015).

Therefore, we characterized $E T$, the water balance and energy budget of a pepper field in MHRB in this study. The objective of this study is to promote a better understanding of energy and hydrologic processes in vegetable fields to improve the agricultural water use efficiency and sustainable irrigation water management in arid lands.

\section{Materials and methods}

\subsection{Study area}

The experimental field (Fig. 1) was located in the arid MHRB in Gansu Province, Northwest China. Annual precipitation is low with an arid and cold climate (Jiang et al., 2015).

\subsection{Observations, data collection and quality ensurance}

The field experiments were conducted in"Heihe Watershed Allied Telemetry Experimental Research" (HiWATER) (Li et al., 2013; Xu et al., 2013) project from June to September 2012. The pepper (Capsicum annuum L.) was sowed on June 8, and harvested on Sep. 19. The soil is silt loam. Fertilization and irrigation practices were set in accordance with the practices of local farmers and companies. The following measurements were conducted in the pepper field.

The sensible heat flux and latent heat flux were observed with an eddy covariance system (Fig. 1), including a three-dimensional sonic anemometer (CSAT3, Campbell Scientific Inc., Logan, USA) and a fast-response infrared gas analyzer (LI7500A, LI-COR Inc., Lincoln, Nebraska, USA), with a sampling frequency $10 \mathrm{~Hz}$. The averages were automatically calculated and recorded every $30 \mathrm{~min}$. ET was derived from the $L E$ data. The consistency of the EC systems and data quality were guaranteed by five procedures, such as errors minimization by the consistency test, raw data procession using the EdiRe software package, empirical gap filling of missing data, and so on (Ran et al., 2016). The missing data were gap-filled using the 'look-up' table method (Falge et al., 2001). Meteorological data, including wind speed and direction, precipitation, air pressure, air temperature and humidity were recorded at an automatic weather station (AWS) (Campbell Co., Ltd.). A CNR-4 radiometer (Kipp \& Zonen, Netherlands) was set at $2 \mathrm{~m}$ above the ground to observe the upward and downward components of longwave and shortwave radiations.

Soil heat flux was measured by two heat flux plates (HFP01SC, Hukseflux, Netherlands) in the row at 0.05 $\mathrm{m}$ below the ground. Time domain reflectometry (TDR) (TRIME-PICO IPH, Germany) system was used to measure soil moisture in seven layers to a depth of $100 \mathrm{~cm}$ in the pepper field. HiWATER team carried out comparative work before the experiment and found that for the saturated soil, compared with the gravimetric method, a mean underestimation of the TDR was 0.025 (Gao et al., 2014). Deep percolation was calculated using the water balance method.

The energy closure balance was shown in Fig. 2 and Table 1 . The average energy closure ratio " $H+L E$ )$/\left(R_{n}-G\right)$ " in the pepper field exceeded $90 \%$, which indicated that the reliability of the EC measurements 
was high.

Precipitation and irrigation in the pepper field are shown in Fig. 3, which indicates that irrigation was the primary source of water.

\subsection{Leaf area index (LAI) and fractional vegetation coverage (FVC) estimation based on thermal images}

To measure and monitor the vegetation coverage and its variations, we applied the concept of $F V C$ (Bian et al., 2017; Jiapaer et al., 2011). The definition of $F V C$ is given by Zhang et al. (2001).FVC was retrieved from the Normalized Difference Vegetation Index (NDVI ) (Badzmierowski et al., 2019; Ricci et al., 2019), which is the most commonly used index for measuring plant performance or stress indicator:

where Red is the reflectance in the red band and NIR is the reflectance in the near-infrared band.

The TIF files of infrared images were exported from SmartView fluke, and were opened with ENVI5.3 to obtain images of four bands. NDVIgrayscale images were calculated using formula (1).

FVC was calculated by pixel bisection model (Li, 2003; Deng et al., 2021).

using $5 \%$ confidence interval, NDVIs is the $N D V I$ value with $5 \%$ cumulative percentage, and NDVIv is the NDVIvalue with $95 \%$ cumulative percentage. The vegetation coverage value is the average value of statistical data for $F V C$.

LAI was calculated using NDVI (Yan, 2018).

We measured the thermal images of the surfaces every two hours in the daytime during the growth stage of pepper by an IR Flexcam Ti55 Thermal Imager (Fluke Corp., USA) (Fig. 1). An example of the thermal images of the pepper field was shown in Fig. 4, which indicated that the surface temperature of the pepper plant was lower than the soil.

\section{Results and discussion}

\subsection{FVC, LAI and Evapotranspiration}

The crop $F V C$ for pepper was $0.25-0.54$ (Fig. 5). The $F V C$ increased from the beginning of the experiment to the middle of the growth stage of the pepper, and reached the highest value on July 26, thereafter decreased gradually (Fig. 5), which reflected the variation process of growth and maturation of the pepper. The LAI for pepper increased in the first two months, then decreased thereafter (Fig. 5), which is similar with several reports (Sezen et al., 2014; Huo et al., 2015; Cándido et al., 2017; Yue et al., 2018).

The total ET in the growing season in the pepper field was $368 \mathrm{~mm}$ (Fig. 6). The daily average $E T$ was 4.23 mm. After Aug. 4, the daily ET decreased (Fig. 6) because leaves withered gradually during the maturation stage (Fig. 5). The peak values of ET on June 29 and July 31 were higher than those on Aug. 21 and Sep. 14 (Fig. 7). On July 31, ET at 21:00 was $-0.05 \mathrm{~mm}$ (Fig. 7b), which indicated dew formation in the pepper field.

\subsection{Soil water content}

The soil water content was relatively high in the pepper field (Fig. 8). The field capacity of silt loam in MHRB was about $33 \%$ ( $\mathrm{Li}$ et al., 2016). The soil water content exceeded the field capacity frequently, indicating that over-irrigation had occurred. At a depth of 60-100 cm, the soil water content throughout the growth stage in the pepper field was higher than 0.4 (Fig. 8a). In most cases the soil water content from $60-100 \mathrm{~cm}$ depth was higher than 0-20 cm due to ET . Wang et al. (2011) also showed that soil water content at $50 \mathrm{~cm}$ in farmland was relatively high because $E T$ mainly consumes soil water above a depth of $50 \mathrm{~cm}$. The daily variation amplitude of soil moisture at depth $2 \mathrm{~cm}$ was the highest among all depths, whereas $100 \mathrm{~cm}$ was the lowest (Fig. 8a). The soil water content increased with soil depth from $2 \mathrm{~cm}$ to $60 \mathrm{~cm}$, and decreased from $60 \mathrm{~cm}$ to $100 \mathrm{~cm}$ (Fig. 8a). 
The distribution of soil water content in the soil profiles (Fig. 8b) showed that the soil water content in the top soil layer $(0-10 \mathrm{~cm})$ was the lowest in the entire soil profile. Yang et al. (2015) reported that seed maize obtained water primarily from 0-10 cm soil layer, with a median absorption ratio of $87 \pm 15 \%$ in MHRB, and a large amount of irrigation water was lost as deep leakage. In the pepper field, the soil water content was highest at a depth of $60 \mathrm{~cm}$ (Fig. 8b). The soil water content was also relatively high at a depth of 100 $\mathrm{cm}$, which easily resulted in high percolation (Fig. 9), suggesting that the current volume of irrigation in MHRB should be reduced to save water.

The FVC in middle and late August was higher than that in June (Fig. 5), whereas the ET in middle and late August was lower than that in June (Fig. 6) because the soil water content in middle and late August was lower than that in June (Fig. 8). Markos and Radoglou (2021) reported that evapotranspiration was mostly affected by soil moisture and net radiation.

\subsection{Water budget}

Characterizing the water budgets during the growth stage in the pepper field (Fig. 9) showed that the amount of ET was lower than irrigation, indicating that over-irrigation had been applied to the fields. The water inputs (precipitation and irrigation) totaled $563 \mathrm{~mm}$, or 1.5 times $E T$. These values showed that total irrigation amount was too high to be used effectively, and a large volume of excess water percolated into the deep soil layers in the field (Fig. 9). TheET in the pepper field was $368 \mathrm{~mm}, 196 \mathrm{~mm}$ lower than the water inputs (precipitation and irrigation) (Fig. 9). Irrigation water could be conserved $301 \mathrm{~mm}$ for the pepper field, in case that percolation was avoided. The deep percolations accounted for $74 \%$ of the total irrigation inputs (Fig. 9), which was consistent with the finding of $\mathrm{Li}$ (2020) who reported that deep leakage below the $1.5 \mathrm{~m}$ soil occupied $68 \%$ of irrigation water during the growth stage of maize in MHRB. Li et al. (2015) also indicated that deep percolation was higher than transpiration due to over-irrigation in a seed corn farmland in MHRB. High leakage was also mentioned by Tong et al. (2007), Zhao et al. (2010), Li et al. (2012) and Jiang et al. (2015) in northwestern China, and these authors also noted that this condition led to low irrigation efficiency, which indicated that appropriate irrigation measures should include adjusting irrigation schedule as well as employing upgraded irrigation methods.

Water use efficiency was low in MHRB because of the excessive use of irrigation water and inequity of water delivery. Therefore, the irrigation amount (per time and total) should be reduced to achieve high water use efficiency; the field may be irrigated more frequently with less water per time to avoid large deep percolation and maintain proper soil moisture, especially in arid regions. In fact, Jiang et al. (2015) reported that improving water transfer and irrigation management may bring about a $30 \%$ reduction of deep leakage.

The experimental field in our study in MHRB was owned by commercial companies, which aim to achieve high yields rather than saving water. Hence, an appropriate water price policy could encourage water conservation at both the farm and canal levels.

\subsection{Energy budget and fluxes variations}

During the entire growth season, the average energy closure ratio " $H+L E) /\left(R_{n}-G\right)$ " in the pepper field exceeded $90 \%$ (Table 1). The average latent heat flux accounted for over $80 \%$ of $R_{n}$, which indicated that $E T$ consumed a large amount of radiation. Tian et al. (2017) indicated that irrigation supplied enough water for $E T$ and thus increased $L E$. The value of $L E / R_{n}$ throughout the entire growth period in our study is similar with a cotton field (Tian et al., 2017) and even a paddy field (Liu et al., 2015), but higher than those have been indicated in several literatures. Taking an example, a figure of $59 \%$ has been showed in the North China Plain (Lei and Yang, 2010). In September, the sensible heat flux accounted for over $20 \%$ of $R_{n}$ because of a decline in $L E$ as leaf area decreased during the crop maturation stage in our study (Table 1); these results are accordance with report of Wu et al. (2006). In July, the $L E / R_{n}$ was the highest among all months, whereas $H / R_{n}$ was the lowest due to the highest values of $F V C$ and $L A I$ in July (Fig. 5). The $L E$ is the primary turbulent flux, which is 8 times $H$ in the pepper field. Our research agreed with a report on cornfields in northwestern China (Ding et al., 2010). 
The maximum daily $R_{n}$ was observed from 12:30-14:30 (Fig. 10), which is accordance with the results from a cultivated area in West Africa (Mamadou et al., 2014). With the exception of August, which had many cloudy and rainy days, the peak value of $R_{n}$ was about $600 \mathrm{~W} \mathrm{~m}^{-2}$ in other three months (Fig. 10). The daily cycle of $R_{n}$ has direct effect on turbulent fluxes, which exhibited a similar diurnal shape except that $H$ was slightly shifted. $L E$ generally rose in the morning along with net radiation, whereas it declined more slowly in the late afternoon (Fig. 10). Overall, a large portion of $R_{n}$ was converted into latent heat flux; this value reached $400 \mathrm{~W} \mathrm{~m}^{-2}$ at approximately 14:00, except during September. Positive latent heat fluxes were observed from the evening to midnight (Fig. 10), which can likely be attributed to the advection of dry air (from the desert around the oasis) over a wet surface. Mauder et al. (2007) reported a similar phenomenon in Nigeria.

Except during September, $G$ and $H$ were similar in the pepper field (Fig. 10). The maximum values of soil heat flux were $28-60 \mathrm{~W} \mathrm{~m}^{-2}$ (Fig. 10), which were slightly higher than that in an Inner Mongolian steppe ecosystem (Hao et al., 2007). The slightly negative value of $G$ during night (Fig. 10) indicated that energy was transmitted from the soil to the surface, which was similar to other crop fields in northwestern China (Chen et al., 2016). The flux residual (Res ) reached its peak value in the morning (Fig. 10), which is consistent with the results of Chow et al. (2014).

Net radiation has a significant linear positive correlation with latent heat flux (Fig. 11) because of the high water supply. The linear slope of the relationship between net radiation and $L E$ in the HRB (Fig. 11) was similar to the slope in the Shiyanghe River Basin, another arid region of northwestern China (Ding et al., 2013).

\subsection{Over-irrigation in MHRB and the potential strategies for water conservation}

Hydrological processes in MHRB are greatly affected by human activities, exceeding climate change (Liu et al., 2008; Luo et al., 2016). Over-irrigation of arid oasis has been a challenge in China for water saving (Tan, 2019), but few measures have been effectively applied by farmers and companies because of lacking practicable water management advices. Deep percolation was commonly high in MHRB due to over-irrigation (Jiang et al., 2015; Li et al., 2015). Although irrigation is highly beneficial for agriculture, it has many negative environmental impacts, including pollution and depletion of surface and groundwater resources (Pereira et al., 2002).

Poor water management and the push for greater economic profits caused over-irrigation (Zhou et al., 2014a). In fact, except for deep percolation, yields have not been enhanced and the water use efficiency is low in conditions of over-irrigation. Irmak et al. (2016) reported that over-irrigation caused a decrease in yield. Su et al. (2014) also reported that irrigation water use efficiency decreased with increasing irrigation amount on sandy farmland in MHRB. Water demand of spring crops would be satisfied by a $40 \%$ of current irrigation quota of each irrigation event with a great decrease of deep percolation and an increase of crop water utilization in MHRB ( $\mathrm{Li}, 2020)$.

Osroosh et al. (2015) suggested that over-irrigation could be avoided using automatic irrigation. Meng et al. (2017) reported that water diversion density was oversize and should be reduced by $34.8 \%$ in MHRB, therefore allocating limited water resources reasonably, popularizing water saving projects, strategies (Kharrazi et al., 2016) and measures industriously are the main methods to improve oasis water use efficiency. In addition, wet or dry year should be considered in irrigation schedule. Chen et al. (2015) indicated that irrigation volume usually did not change every year, although the irrigation demand of vegetation declined in wet years. There is a large room for the improvement of water use efficiency and water conservation in arid regions throughout China.

\section{Conclusions}

The amount of ET was lower than irrigation. After Aug. 4, the daily ET decreased during the maturation stage. The soil water content was higher than the field capacity frequently, indicating that over-irrigation had occurred. The water inputs (precipitation and irrigation) were 1.5 times $E T$, and the deep percolations 
accounted for $74 \%$ of the total irrigation inputs. Irrigation water could be conserved $301 \mathrm{~mm}$ for the pepper field, in case that percolation (below the $1 \mathrm{~m}$ soil) was avoided. Therefore, the irrigation amount (per time and total) should be reduced to achieve high water use efficiency (WUE ). The latent heat flux ( $L E$ ) consumed more than $80 \%$ of the net radiation $\left(R_{n}\right)$. In July, the $L E / R_{n}$ was the highest among all months, whereas $H / R_{n}$ was the lowest due to the highest values of $F V C$ and $L A I$ in July. The net radiation had a significant positive linear correlation with the latent heat flux because of the high water supply. Our study showed that there was considerable room for water conservation in MHRB.

\section{Acknowledgements}

We acknowledge, with gratitude, the financial support from the National Natural Science Foundation of China (91025008, 31270748 and 31470707), National Key R\&D Program of China (2021YFC3001000), and Hubei Key Laboratory of Water System Science for Sponge City Construction (Wuhan University) (2020-05). Great thanks also to the Heihe Watershed Applied Telemetry Experimental Research (HiWATER) project for their supports on EC observation and other supports during our field experiment. Special thank is also owed to Elsevier Language Editing and a native-speaking senior editor for their efforts in improving the grammar and quality of this paper.

\section{References}

Badzmierowski, M.J., McCall, D.S., Evanylo, G., 2019. Using hyperspectral and multispectral indices to detect water stress for an urban turfgrass system. Agronomy-Basel 439(9), 1-15. https://doi.org/10.3390/agronomy9080439.

Bian, J.H., Li, A.N., Zhang, Z.J., Zhao, W., Lei, G.B., Yin, G.F., Jin, H.A., Tan, J.B., Huang, C.Q., 2017. Monitoring fractional green vegetation cover dynamics over a seasonally inundated alpine wetland using dense time series HJ-1A/B constellation images and an adaptive endmember selection LSMM model. Remote Sens. Environ. 197, 98-114. https://doi.org/10.1016/j.rse.2017.05.031.

Candido, M.P., Carlos, R.A., Waldo, O.B., Hector, F.M., 2017. Estimation of leaf area index and yield of greenhouse-grown poblano pepper. Ingenieria Agricola y Biosistemas 9(1), 37-50. https://doi.org/10.5154/r.inagbi.2017.04.009.

Chen, X., Yu, Y., Chen, J., Zhang, T., Li, Z., 2016. Seasonal and interannual variation of radiation and energy fluxes over a rain-fed cropland in the semi-arid area of Loess Plateau, northwestern China. Atmos. Res. 176-177, 240-253. https://doi.org/10.1016/j.atmosres.2016.03.003.

Chen, Y.J., Mcfadden, J.P., Clarke, K.C., Roberts, D.A., 2015. Measuring spatio-temporal trends in residential landscape irrigation extent and rate in Los Angeles, California using SPOT-5 satellite imagery. Water Resour. Manag. 29(15), 5749-5763. https://doi.org/10.1007/s11269-015-1157-x.

Cheng, C.H., Nnadi, F., Liou, Y.A., 2014. Energy budget on various land use areas using reanalysis data in Florida. Adv. Meteorol. 2014, 1-13. https://doi.org/10.1155/2014/232457.

Chow, W.T.L., Volo, T.J., Vivoni, E.R., Jenerette, G.D., Ruddell, B.L., 2014. Seasonal dynamics of a suburban energy balance in Phoenix, Arizona. Int. J. Climatol. 34(15), 3863-3880. https://doi.org/10.1002/joc.3947.

Deng, Z., Lu, Z., Wang, G., Wang, D., Ding, Z., Zhao, H., Xu, H., Shi, Y., Cheng, Z., Zhao, X., 2021. Extraction of fractional vegetation cover in arid desert area based on Chinese GF-6 satellite. Open Geosci. 13(1), 416-430. https://doi.org/10.1515/GEO-2020-0241.

Ding, R., Kang, S., Li, F., Zhang, Y., Tong, L., 2013. Evapotranspiration measurement and estimation using modified Priestley-Taylor model in an irrigated maize field with mulching. Agric. For. Meteorol. 168, 140-148. https://doi.org/10.1016/j.agrformet.2012.08.003.

Ding, R.S., Kang, S.Z., Li, F.S., Zhang, Y.Q., Ling, T., Sun, Q.Y., 2010. Evaluating eddy covariance method by large-scale weighing lysimeter in a maize field of northwest China. Agric. Water Manage. 98(1), 87-95. 
https://doi.org/10.1016/j.agwat.2010.08.001.

Falge, E., Baldocchi, D., Olson, R., Anthoni, P., Aubinet, M., Bernhofer, C., Burba, G., Ceulemans, R., Clement, R., Dolman, H., Granier, A., Gross, P., Grunwald, T., Hollinger, D., Jensen, N., Katul, G., Keronen, P., Kowalski, A., Lai, C.T., Law, B.E., Meyers, T., Moncrieff, J., Moors, E., Munger, J.W., Pilegaard, K., Rannik U, Rebmann, C., Suyker, A., Tenhunen, J., Tu, K., Verma, S., Vesala, T., Wilson, K., Wofsy, S., 2001. Gap filling strategies for defensible annual sums of netecosystem exchange. Agric. For. Meteorol. 107(1), 43-69. https://doi.org/10.1016/S0168-1923(00)00225-2.

Fu, L., Zhang, L., He, C., 2014. Analysis of agricultural land use change in the middle reach of the Heihe River Basin, Northwest China. Int. J. Environ. Res. Public Health 11(3), 2698-2712. https://doi.org/10.3390/ijerph110302698.

Gao, S.G., Zhu, Z.L., Liu, S.M., Jin, R., Yang, G.C., Tan L., 2014. Estimating the spatial distribution of soil moisture based on Bayesian maximum entropy method with auxiliary data from remote sensing. Int. J. Appl. Earth Obs. Geoinf. 32, 54-66. https://doi.org/10.1016/j.jag.2014.03.003.

Gao, X., Mei, X., Gu, F., Hao, W., Gong, D., Li, H., 2018. Evapotranspiration partitioning and energy budget in a rainfed spring maize field on the Loess Plateau, China. Catena 166, 249-259. https://doi.org/10.1016/j.catena.2018.04.008.

Haghighi, E., Kirchner, J.W., 2017. Near-surface turbulence as a missing link in modeling evapotranspiration-soil moisture relationships. Water Resour. Res. 53(7), 5320-5344. https://doi.org/10.1002/2016WR020111.

Hao, Y.B., Wang, Y.F., Mei, X.R., Huang, X.Z., Cui, X.Y., Zhou, X.Q., Niu, H.S., 2007. $\mathrm{CO}_{2}, \mathrm{H}_{2} \mathrm{O}$ and energy exchange of an Inner Mongolia steppe ecosystem during a dry and wet year. Acta Oecol. 33(2), 133-143. https://doi.org/10.1016/j.actao.2007.07.002.

Huo, S.L., Xie, J.M., Shen, L., Qi, G.B., Wang, X.L., Xue, J., Yang, R., Yu, H.X., He, Z.X., 2015. Effect of high nitrogen controlled-release fertilizer on physiological growth and dry matter distribution in different organs of pepper. Chin. Agric. Sci. Bull. 31(22), 105-110.

Irmak, S., Djaman, K., Rudnick, D.R., 2016. Effect of full and limited irrigation amount and frequency on subsurface drip-irrigated maize evapotranspiration, yield, water use efficiency and yield response factors. Irrig. Sci. 34(4), 271-286. https://doi.org/10.1007/s00271-016-0502-z.

Ji, X.B., Zhao, W.Z., Kang, E.S., Zhang, Z.H., Jin, B.W., 2011. Carbon dioxide, water vapor, and heat fluxes over agricultural crop field in an arid oasis of Northwest China, as determined by eddy covariance. Environ. Earth Sci. 64(3), 619-629. https://doi.org/10.1007/s12665-010-0883-x.

Jiapaer, G., Chen, X., Bao, A.M., 2011. A comparison of methods for estimating fractional vegetation cover in arid regions. Agric For. Meteorol. 151(12), 1698-1710. https://doi.org/10.1016/j.agrformet.2011.07.004.

Jiang, Y., Xu, X., Huang, Q., Huo, Z., Huang, G., 2015. Assessment of irrigation performance and water productivity in irrigated areas of the middle Heihe River Basin using a distributed agro-hydrological model. Agric. Water Manage. 147, 67-81. https://doi.org/10.1016/j.agwat.2014.08.003.

Kharrazi, A., Akiyama, T., Yu, Y.D., Li, J., 2016. Evaluating the evolution of the Heihe River Basin using the ecological network analysis: Efficiency, resilience, and implications for water resource management policy. Sci. Total Environ. 572, 688-696. https://doi.org/10.1016/j.scitotenv.2016.06.210.

Knipper, K.R., Kustas, W.P., Anderson, M.C., Nieto, H., Alfieri, J.G., Prueger, J.H., Hain, C.R., Gao, F., McKee, L.G., Alsina, M.M., Sanchez, L., 2020. Using high-spatiotemporal thermal satellite ET retrievals to monitor water use over California vineyards of different climate, vine variety and trellis design. Agric. Water Manage. 241. https://doi.org/10.1016/j.agwat.2020.106361. 
Lei, H., Yang, D., 2010. Interannual and seasonal variability in evapotranspiration and energy partitioning over an irrigated cropland in the North China Plain. Agric. For. Meteorol. 150(4), 581-589. https://doi.org/10.1016/j.agrformet.2010.01.022.

Li, D.F., 2020. Quantifying water use and groundwater recharge under flood irrigation in an arid oasis of northwestern China. Agric. Water Manage. 240, 106326. https://doi.org/10.1016/j.agwat.2020.106326.

Li, D.S., Ji X.B., Zhao L.W., 2015. Simulation of seed corn farmland soil moisture migration regularity in the midstream of the Heihe River Basin. Arid Zone Res. 32(03), 467-475 (in Chinese with English abstract). https://doi.org/10.13866/j.azr.2015.03.08.

Li, J., Zhu, T., Mao, X., Adeloye, A.J., 2016. Modeling crop water consumption and water productivity in the middle reaches of Heihe River Basin. Comput. Electron. Agric. 123, 242-255. https://doi.org/10.1016/j.compag.2016.02.021.

Li, M.M., 2003. The Method of Vegetation Fraction Estimation by Remote Sensing. University of Chinese Academy of Sciences (Institute of Remote Sensing Applications), Beijing.

Li, X., Cheng G.D., Ge, Y.C., Li, H.Y., Han, F., Hu, X.L., Tian, W., Tian, Y., Pan, X.D., Nian, Y.Y., Zhang, Y.N., Ran, Y.H., Zheng, Y., Gao, B., Yang, D.W., Zheng, C.M., Wang, X.S., Liu, S.M., Cai, X.M., 2018. Hydrological cycle in the Heihe River Basin and its implication for water resource management in endorheic basins. J. Geophys. Res.-Atmos. 123(2), 890-914. https://doi.org/10.1002/2017JD027889.

Li, X., Cheng G.D., Liu, S.M., Xiao, Q., Ma, M.G., Jin, R., Che, T., Liu, Q.H., Wang, W.Z., Qi, Y., Wen, J.G., Li, H.Y., Zhu, G.F., Guo, J.W., Ran, Y.H., Wang, S.G., Zhu, Z.L., Zhou, J., Hu, X.L., Xu, Z.W., 2013. Heihe Watershed Allied Telemetry Experimental Research (HiWATER): Scientific objectives and experimental design. Bull. Amer. Meteorol. Soc. 94(8), 1145-1160. https://doi.org/10.1175/BAMSD-12-00154.1.

Li, Y., Kinzelbach, W., Zhou, J., Cheng, G.D., 2012. Modelling irrigated maize with a combination of coupled-model simulation and uncertainty analysis in the northwest of China. Hydrol. Earth Syst. Sci. 16(155), 1465-1480. https://doi.org/10.5194/hess-16-1465-2012.

Li, Z.S., Jia, L., Hu, G.C., Lu, J., Zhang, J.X., Chen, Q.T., Wang, K., 2015. Estimation of growing season daily $E T$ in the middle stream and downstream areas of the Heihe River Basin using HJ-1 data. IEEE Geosci. Remote Sens. Lett. 12(5), 948-952. https://doi.org/10.1109/LGRS.2014.2368694.

Liu, W., Wang, T., Zheng, H., Ma, Z.Z., 2008. Drivers forces of different type of land desertification in Heihe River Basin. J. Desert Res. 28(4), 634-640.

Liu, X.Y., Yang, S.H., Li, J.W., Xu, J.Z., Liu, M., 2015. Characteristics and law analysis of energy flux in southern water-saving irrigation paddy field. Transactions Chinese Soc. Agric. Mach. 46(05), 83-92 (in Chinese with English abstract). https://doi.org/10.6041/j.issn.1000-1298.2015.05.013.

Luo, K., Tao, F., Moiwo, J.P., Xiao, D., 2016. Attribution of hydrological change in Heihe River Basin to climate and land use change in the past three decades. Sci. Rep. 6, 33704. https://doi.org/10.1038/srep33704.

Ma, Y., Liu, S., Zhang, F., Zhou, J., Jia, Z., Song, L., 2015. Estimations of regional surface energy fluxes over heterogeneous oasis-desert surfaces in the middle reaches of the Heihe River during HiWATER-MUSOEXE. IEEE Geosci. Remote Sens. Lett. 12(3), 671-675. https://doi.org/10.1109/LGRS.2014.2356652.

Mamadou, O., Cohard, J.M., Galle, S., Awanou, C.N., Diedhiou, A., Kounouhewa, B., Peugeot, C., 2014. Energy fluxes and surface characteristics over a cultivated area in Benin: daily and seasonal dynamics. Hydrol. Earth Syst. Sci. 18(3), 893-914. https://doi.org/10.5194/hess-18-893-2014.

Markos, N., Radoglou, K., 2021. Estimation of ecosystem evapotranspiration in a Robinia pseudoacacia L. plantation with the use of the eddy covariance technique and modeling approaches. Water Sci. Tech.-W Sup. 21(6), 2553-2568. https://doi.org/10.2166/ws.2021.142. 
Mauder, M., Jegede, O.O., Okogbue, E.C., Wimmer, F., Foken, T., 2007. Surface energy balance measurements at a tropical site in West Africa during the transition from dry to wet season. Theor. Appl. Climatol. 89(3-4), 171-183. https://doi.org/10.1007/s00704-006-0252-6.

Meng, J.J., Wang, J.W., You, N.S., Wang, Y., Zhou, Z., 2017. Spatiotemporal differentiation of water allocation efficiency in oasis irrigated area in the middle reaches of the Heihe River. Res. Soil Water Conserv. 24, 173-180 (in Chinese with English abstract). https://doi.org/10.13869/j.cnki.rswc.2017.01.022.

Osroosh, Y., Troy Peters, R., Campbell, C.S., Zhang, Q., 2015. Automatic irrigation scheduling of apple trees using theoretical crop water stress index with an innovative dynamic threshold. Comput. Electron. Agric. 118, 193-203. https://doi.org/10.1016/j.compag.2015.09.006.

Pereira, L.S., Oweis, T., Zairi, A., 2002. Irrigation management under water scarcity. Agric. Water Manage. 57(3), 175-206. https://doi.org/10.1016/S0378-3774(02)00075-6.

Qi, S.Z., Luo, F., 2005. Water environmental degradation of the Heihe River Basin in arid northwestern China. Environ. Monit. Assess. 108(1-3), 205-215. https://doi.org/10.1016/S0378-3774(02)00075-6. https://doi.org/10.1007/s10661-005-3912-6.

Ran, Y., Li, X., Sun, R., Kljun, N., Zhang, L., Wang, X., Zhu, G., 2016. Spatial representativeness and uncertainty of eddy covariance carbon flux measurements for upscaling net ecosystem productivity to the grid scale. Agric. For. Meteorol. 230-231, 114-127. https://doi.org/10.1016/j.agrformet.2016.05.008.

Ricci, G.F., Romano, G., Leronni, V., Gentile, F., 2019. Effect of check dams on riparian vegetation cover: A multiscale approach based on field measurements and satellite images for Leaf Area Index assessment. Sci. Total Environ. 657, 827-838. https://doi.org/10.1016/j.scitotenv.2018.12.081.

Roost, N., Cai, X.L., Molden, D., Cui, Y.L., 2008. Adapting to intersectoral transfers in the Zhanghe Irrigation System, China: Part II: Impacts of in-system storage on water balance and productivity. Agric. Water Manage. 95(6), 698-706. https://doi.org/10.1016/j.agwat.2008.01.011.

Sezen, S.M., Yazar, A., Daşgan, Y., Yucel, S., Akyıldız, A., Tekin, S., Akhoundnejad, Y., 2014. Evaluation of crop water stress index (CWSI) for red pepper with drip and furrow irrigation under varying irrigation regimes. Agric. Water Manage. 143, 59-70. https://doi.org/10.1016/j.agwat.2014.06.008.

Su, Y.Z., Zhang, Z.H., Yang, R., 2014. Amount of irrigation and nitrogen application for maize grown on sandy farmland in the marginal oasis in the middle of Heihe River Basin. Acta Agron. Sin. 33(12), 2007-2015. https://doi.org/10.3321/j.issn:0496-3490.2007.12.014.

Taghvaeian, S., Neale, C.M.U., 2011. Water balance of irrigated areas: a remote sensing approach. Hydrol. Process. 25(26), 4132-4141. https://doi.org/10.1002/hyp.8371.

Tan, M.H., 2019. Mismatch between crop water requirements and irrigation in Heihe River Basin, Northwestern China. Irrig. Sci. 37(1), 95-103. https://doi.org/10.1007/s00271-018-0608-6.

Tian, F., Qiu, G.Y., Yang, Y.H., Lü, Y.H., Xiong, Y., 2013. Estimation of evapotranspiration and its partition based on an extended three-temperature model and MODIS products. J. Hydrol. 498, 210-220. https://doi.org/10.1016/j.jhydrol.2013.06.038.

Tian, F.Q., Yang, P.J., Hu, H.C., Liu, H., 2017. Energy balance and canopy conductance for a cotton field under film mulched drip irrigation in an arid region of northwestern China. Agric. Water Manage. 179, 110-121. https://doi.org/10.1016/j.agwat.2016.06.029.

Tong, L., Kang, S.Z., Zhang, L., 2007. Temporal and spatial variations of evapotranspiration for spring wheat in the Shiyang River Basin in northwest China. Agric. Water Manage. 87(3), 241-250. https://doi.org/10.1016/j.agwat.2006.07.013.

Uddin, J., Hancock, N.H., Smith, R.J., Foley, J.P., 2013. Measurement of evapotranspiration during sprinkler irrigation using a precision energy budget (Bowen ratio, eddy covariance) methodology. Agric. Water Manage. 
116, 89-100. https://doi.org/10.1016/j.agwat.2012.10.008.

Wang, Y.Q., Shao, M.A., Zhu, Y.J., Liu, Z.P., 2011. Impacts of land use and plant characteristics on dried soil layers in different climatic regions on the Loess Plateau of China. Agric. For. Meteorol. 151(4), 437-448. https://doi.org/10.1016/j.agrformet.2010.11.016.

Wu, J.K., Ding, Y.J., Wang, G.X., Shen, Y.P., Yusuke, Y., Jumpei, K., 2006. Energy balance of irrigated intercropping field in the middle reaches of Heihe River Basin. Chin. Geogr. Sci. 16(3), 243-248. https://doi.org/10.1007/s11769-006-0243-7.

Xu, Z.W., Liu, S.M., Li, X., Shi, S.J., Wang, J.M., Zhu, Z.L., Xu, T.R., Wang, W.Z., Ma, M.G, 2013. Intercomparison of surface energy flux measurement systems used during the HiWATER-MUSOEXE. J. Geophys. Res. Atmos. 118(23), 13140-13157. https://doi.org/10.1002/2013JD020260.

Xu, Z.W., Ma, Y.F., Liu, S.M., Shi, W.J., Wang, J.M., 2017. Assessment of the energy balance closure under advective conditions and its impact using remote sensing data. J. Appl. Meteor. Climatol. 56(1), 127-140. https://doi.org/10.1175/JAMC-D-16-0096.1.

Yan, M.Q., 2018. Study on remote sensing extraction of vegetation coverage based on LAI. Beijing Forestry University, Beijing. https://doi.org/10.26949/d.cnki.gblyu.2018.000459.

Yang, B., Wen, X.F., Sun, X.M., 2015. Irrigation depth far exceeds water uptake depth in an oasis cropland in the middle reaches of Heihe River Basin. Sci. Rep. 5(1), 1688-1897, 1-12. https://doi.org/10.1038/srep15206.

Yue, Y., Zhao, Z., Peng, Z., Li, R., Li, L., Feng, E., Sun, C., 2018. Simulation on leaf area and dry matter production of Chilli pepper. Southwest China J. Agric. Sci. 31, 2653-2658. https://doi.org/10.16213/j.cnki.scjas.2018.12.032.

Zhang, W.B., Fu, S.H., Liu, B.Y., 2001. Error assessment of visual estimation plant coverage. J Beijing Norm Univ (Nat Sci). 37(3), 402-408. https://doi.org/CNKI:SUN:BSDZ.0.2001-03-025.

Zhang, Y.J., Wang, S.L., Wang, H., Wang, R., Wang, X.L., Li, J., 2018. Crop yield and soil properties of dryland winter wheat-spring maize rotation in response to 10-year fertilization and conservation tillage practices on the Loess Plateau. Field Crops Res. 225, 170-179. https://doi.org/10.1016/j.fcr.2018.07.003.

Zhao, W.Z., Liu, B., Zhang, Z.H., 2010. Water requirements of maize in the middle Heihe River Basin, China. Agric. Water Manage. 97(2), 215-223. https://doi.org/10.1016/j.agwat.2009.09.011.

Zhou, J., Wu, X.J., Li, H.X., Li, Y., Zhong, B., Pan, X.D., 2014a. Improved SEBS model for evaluating irrigation water use efficiency in the middle reaches of the Heihe River. J. Hydraul. Eng. 45(12), 1387-1398 (in Chinese with English abstract). https://doi.org/10.13243/j.cnki.slxb.2014.12.001.

\section{Hosted file}

Study on energy and water balance of pepper field_Figure.docx available at https://authorea. com/users/458383/articles/554953-study-on-energy-and-water-balance-of-pepper-field-inarid-areas

\section{Hosted file}

Study on energy and water balance of pepper field_Table.docx available at https://authorea. com/users/458383/articles/554953-study-on-energy-and-water-balance-of-pepper-field-inarid-areas 